\title{
Bom Retiro
}

Marta Goes ${ }^{1}$

Desde "Paraíso perdido" e "O Livro de Jó", suas primeiras montagens, o Teatro da Vertigem estabeleceu um trânsito de significados entre o espetáculo e sua locação. Em "Paraíso perdido", a frieza solene de uma igreja ressaltou a força poética do tema da expulsão do paraíso. Em "O livro de Jó", os saguões, as enfermarias e a sala de cirurgia de um hospital desativado fizeram reverberar na experiência do espectador o sofrimento do personagem bíblico. Bom Retiro 958 metros leva as relações entre o teatro e o espaço cênico investigadas pelo grupo de Antonio Araújo a um lugar novo. Desta vez, o espaço - o bairro do Bom Retiro - é o tema da encenação. O espetáculo atravessa a própria carne de seu tema. E a recíproca é verdadeira.

Criado a partir de um estudo sobre o bairro, um dos centros do comércio e da indústria de confecção de São Paulo, o espetáculo fez o lugar falar praticamente em primeira pessoa. À sua passagem, no curto trajeto noturno em que ele se desenrola, pelas ruas da região, vão saltando diante de nossos olhos personagens e fantasmas locais. São compradores, operários, seguranças, vendedores, moradores de rua e viciados em crack, entre outras figuras. Representam histórias individuais e tribos urbanas, mas também questões teóricas, como estereótipos impostos pela moda, fantasias de felicidade e compulsões de consumo. A futilidade da marcha febril de sacoleiros que acontece ali todos os dias encontra uma linda tradução na personagem da mulher que procura, em vão, um vestido vermelho.

Uma das tarefas que a encenação leva a cabo é recortar um espetáculo naquela paisagem dispersiva e estridente. Manter-se visível, dirigir o olhar do espectador para a ação e hierarquizar os elementos do cenário urbano são desafios que o encenador resolve com muita sabedoria e pequeno aparato técnico. Outro feito, talvez o mais singular, é saber se alimentar das fronteiras tênues entre a montagem e o ambiente à sua volta. À medida que as cenas se constroem e se dissolvem pelo trajeto, o espetáculo olha para a cidade e esta olha para o espetáculo.Transeuntes levemente intrigados desviam dos atores, passageiros de ônibus

\footnotetext{
${ }^{1}$ Marta Goes é dramaturga.
} 
se debruçam nas janelas, tentando compreender aquela movimentação inusitada, porteiros sonolentos deslocam por alguns segundo a atenção de seus programas de TV para ver passar a peça teatral. E, estranhamente, essas participações acidentais enriquecem o espetáculo e ajudam a desenhá-lo, em vez de fazê-lo fundir-se ao entorno.

As primeiras cenas, dentro de um shopping center, logo estabelecem a tensão entre o mundo do consumo e a cidade real. Portões que se fecham apressadamente erguem uma espécie de barricada. Lá fora, a pobreza e a violência, lá dentro, um universo artificial feito de luz fria e lojas de nomes esquisitos.

Aos poucos, começam a circular por ali, perturbando a cafonice afluente das vitrines, personagens que habitam o porão daquele mundo: o exército dos trabalhadores clandestinos, representado pelas costureiras. O custo humano da cultura do consumo para todos os envolvidos é um dos temas dominantes do espetáculo, mas questões mais localizadas e imediatas, como a presença incômoda dos craqueiros num cenário que gostaria de ser festivo, aparecem ao longo do percurso. Também a memória do bairro, que já abrigou uma zona boêmia antes da chegada das confecções, é abordada nas pinceladas breves das cenas.

"Bom Retiro" transforma com grande habilidade reflexões complicadas em imagens fortes e sintéticas. A contínua transformação do luxo em lixo pelos ciclos rápidos do consumo é mencionada sem nenhuma palavra, em detalhes como o icônico xadrez Burberry`s num figurino andrajoso. Ou na destinação dos manequins de vitrine ao longo da montagem: tratados inicialmente como clones, acabam, às vezes aos pedaços, nas caçambas de lixo. Um inesquecível desfile de modas num cruzamento, com os atores reproduzindo o andar marcial dos manequins de passarela, comenta os padrões ridículos impostos pela cadeia da moda e do consumo.

As questões levantadas pelo espetáculo já habitam, de modo mais fragmentário, vários espaços de expressão: artigos de jornal, noticiários policiais, reportagens de cadernos de cidades. Mas estão reunidas ali com uma pungência que a poesia e o teatro, na mão de verdadeiros artistas, têm o poder de conferir a seus temas. 